\title{
O POETA
}

Thatiane Prochner é formada em Letras Português / Inglês pela UEPG - Universidade Estadual de Ponta Grossa, Especialista em Língua Portuguesa e Literatura e Mestre em Linguagem, Identidade e Subjetividade pela mesma instituição. Atua na área de Literatura Brasileira, com ênfase na poesia de Carlos Drummond de Andrade.

E-mail: thatianegauche@gmail.com

Caminhávamos eu e ele, lado a lado.

Seus olhos cabisbaixos,

andar vagaroso,

voz baixinha, um tanto rouca.

Contava-me coisas de sua vida.

Tocou-me nos ombros.

Recitava-me versos seus, que eu sabia de cor...

Ao longe, eu observava nós dois, caminhando lado a lado.

Mas já não ouvia sobre as coisas de sua vida.

Quais eram os versos que recitava?

As sombras me turvavam o olhar...

Em volta:

o quarto, a penumbra, a janela, o sonho. 